\title{
OPEN Temperature dependency of excitonic effective mass and charge carrier conduction mechanism in $\mathrm{CH}_{3} \mathrm{NH}_{3} \mathrm{Pbl}_{3-\mathrm{x}} \mathrm{Cl}_{x}$ thin films
}

\begin{abstract}
A. M. M. Tanveer Karim ${ }^{1 凶}$, M. K. R. Khan ${ }^{2 \bowtie}$ \& M. S. Hossain ${ }^{1}$
In this paper we explain the temperature dependence of excitonic effective mass and charge carrier conduction mechanism occurs in $\mathrm{CH}_{3} \mathrm{NH}_{3} \mathrm{Pbl}_{3-\mathrm{x}} \mathrm{Cl}_{x}$ thin films prepared by chemical dip coating (CDC), spray pyrolysis (Spray) and repeated dipping-withdrawing (Dipping). Hall Effect study confirmed that prepared $\mathrm{CH}_{3} \mathrm{NH}_{3} \mathrm{Pbl}_{3-\mathrm{x}} \mathrm{Cl}_{\mathrm{x}}$ samples are $\mathrm{p}$-type semiconductor having carrier concentration of the order of $\sim 10^{16} \mathrm{~cm}^{-3}$. The charge carrier mobility, mean free path and mean free life time were found to decrease with increasing temperature due to polaronic effect. The excitonic effective mass is estimated to $(0.090-0.196) \mathrm{m}_{\mathrm{e}}$ and excitonic binding energy (15-33) meV, well consistent with Wannier-Mott hydrogenic model and the nature of exciton is likely to be Mott-Wannier type. From electrical measurement, it was observed that charge carrier conduction in $\mathrm{CH}_{3} \mathrm{NH}_{3} \mathrm{Pbl}_{3-\mathrm{x}} \mathrm{Cl}_{\mathrm{x}}$ is governed by migration of $\mathrm{I}^{-}$and $\mathrm{CH}_{3} \mathrm{NH}_{3}^{+}$vacancies and vacancy-assisted diffusion processes depending on temperature.
\end{abstract}

Now-a-days, methylammonium lead halide perovskites (MLHP) are regarded worldwide as an emerging material class in the field of photovoltaic and optoelectronics. The typically chemical formula of MLHP is AMX , where $\mathrm{A}$ is the organic/inorganic cation $\left(\mathrm{CH}_{3} \mathrm{NH}_{3}\right), \mathrm{M}$ is a heavy metal cation $(\mathrm{Pb})$ and $\mathrm{X}$ is halide anions (I). When $\mathrm{X}$ site is replaced by another halogen element such as chlorine $(\mathrm{Cl})$ into $\mathrm{AMX}_{3}$, it converts to mixed halide perovskites $\mathrm{CH}_{3} \mathrm{NH}_{3} \mathrm{PbI}_{3-\mathrm{x}} \mathrm{Cl}_{\mathrm{x}}$. This mixed halide perovskites exhibit semiconducting nature with some exciting properties for photovoltaic and optoelectronic device applications. The single-junction solar cell architecture, based on $\mathrm{CH}_{3} \mathrm{NH}_{3} \mathrm{PbI}_{3-\mathrm{x}} \mathrm{Cl}_{\mathrm{x}}$ perovskite, shows power conversion efficiency of $25.5 \%{ }^{1}$. Besides, $\mathrm{CH}_{3} \mathrm{NH}_{3} \mathrm{PbI}_{3-\mathrm{x}} \mathrm{Cl}_{\mathrm{x}}$ thin film shows multi-colored emission ${ }^{2-5}$, second harmonic generation or frequency doubling ${ }^{5}$, bimolecular recombination ${ }^{6}$, trap-assist recombination ${ }^{7}$, strong tunable interband transitions ${ }^{8}$, and ambipolar charge transport ${ }^{9}$. However, mixed halide perovskite suffers a compositional instability due to halide (I, Br) segregation ${ }^{10}$. But a very small addition of $\mathrm{Cl}$ into $(\mathrm{I} / \mathrm{Br})$ lattice restrains the halide phase segregation, improves the charge carrier mobility, carrier lifetime and stability of solar cells without changing the crystallographic domain size ${ }^{11}$. These properties are directly correlated with the temperature dependent charge transport behavior in $\mathrm{CH}_{3} \mathrm{NH}_{3} \mathrm{PbI}_{3-\mathrm{x}} \mathrm{Cl}_{\mathrm{x}}$ and expected to improve device configuration compared to (I/Br) composition.

Up to now, multiple approaches such as transient terahertz $(\mathrm{THz})$ spectroscopy ${ }^{6,12}$, combination of timeresolved terahertz with optical transient reflection spectroscopy (TRTS-TR $)^{13}$, photoluminescence quenching $(\mathrm{PLQ})^{14}$, time resolved electro-absorption spectroscopy ${ }^{15}$, time-of-flight (TOF) photoconductivity ${ }^{16}$ and Hall effect measurement ${ }^{17}$ have been carried out to explore the transport properties of lead halide perovskites. These pioneer studies reveal the presence of non-Langevin charge carriers ${ }^{6}$, strong back-scattering on free carrier dynamics $^{12}$, existence of higher hole mobility compared to electron mobility ${ }^{13}$, large electron-hole diffusion lengths $(>1 \mu \mathrm{m})^{14}$, electric field assisted charge carrier seperation ${ }^{15}$, grain size dependent mobility ${ }^{16}$, and influence of self-doping in carrier concentration ${ }^{17}$. Despite the advancement in deep-seated perceptive in transport behavior, a lot of issues such as charge-carrier type, the mechanisms for restraining carrier mobility, origin of electron-hole recombination rates, donor or acceptor ionization energy, position of Fermi level, effective mass

${ }^{1}$ Department of Physics, Rajshahi University of Engineering \& Technology, Rajshahi 6204, Bangladesh. ${ }^{2}$ Department of Physics, University of Rajshahi, Rajshahi 6205, Bangladesh. ${ }^{\square}$ email: tanveerruphy@ gmail.com; mfkrkhan@yahoo.com 


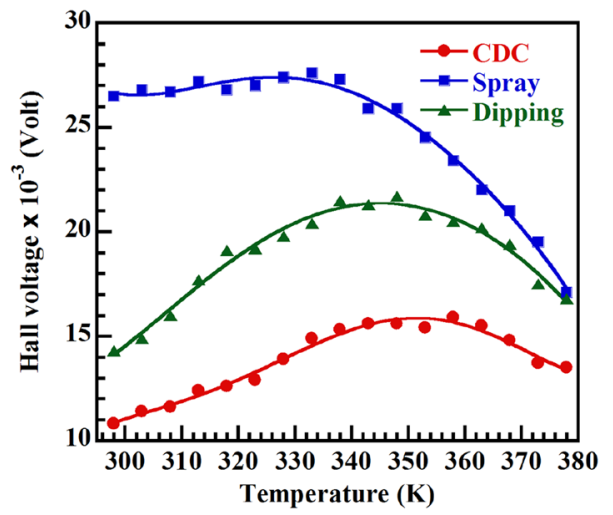

Figure 1. Hall voltage of $\mathrm{CH}_{3} \mathrm{NH}_{3} \mathrm{PbI}_{3-\mathrm{x}} \mathrm{Cl}_{\mathrm{x}}$. Variation of Hall voltage at constant magnetic field of $9.815 \mathrm{KG}$ with temperature for $\mathrm{CH}_{3} \mathrm{NH}_{3} \mathrm{PbI}_{3-\mathrm{x}} \mathrm{Cl}_{\mathrm{x}}$ thin films using Hall measurement setup.

of charge-carriers, grain boundary barrier height, carrier mean free path-life time in $\mathrm{CH}_{3} \mathrm{NH}_{3} \mathrm{PbI}_{3-\mathrm{x}} \mathrm{Cl}_{\mathrm{x}}$ still perplexes the researchers. It is well known that the mixed halide perovskite undergoes a phase transition from orthorhombic-tetragonal-cubic at $160 \mathrm{~K}$ and in between $(315-330) \mathrm{K}$, respectively ${ }^{18,19}$. However, the study of charge carrier dynamics is limited to tetragonal phase while it is also important to explore such properties for cubic phase above room temperature (RT).

Recently, it is reported that charge carries generate self-induced rotation of the organic part $\left(\mathrm{CH}_{3} \mathrm{~N} \mathrm{H}_{3}^{+}\right)$, which polarizes lead halide perovskite lattice to form quasi-particle polarons $\mathrm{s}^{20-25}$. The conception of polaron is used to explain intrinsic electrical properties because it describes the interaction between charge carriers and phonons. The interaction of charge carriers with the organic part has significant influence on the effective mass, temperature and magnetic field dependent carrier transport and electrical conductivity of the mixed halide perovskite material.

In our previous work we report the characterization of nano-crystalline $\mathrm{CH}_{3} \mathrm{NH}_{3} \mathrm{PbI}_{3-\mathrm{x}} \mathrm{Cl}_{\mathrm{x}}$ thin films prepared on glass substrate by chemical dipping-withdrawing $(\mathrm{CDC})^{2}$, spray pyrolysis (Spray) $)^{5}$ and repeated dipping-withdrawing (Dipping) ${ }^{3}$ techniques in an ambient atmosphere. Our study confirmed the presence of tetragonal and mixed cubic-tetragonal phase in $\mathrm{CH}_{3} \mathrm{NH}_{3} \mathrm{PbI}_{3-\mathrm{x}} \mathrm{Cl}_{\mathrm{x}}$ thin film. The film morphology was composed with spherical, rod, cuboid and polyhedral like crystal grains of sizes $100 \mathrm{~nm}$ to $2 \mu \mathrm{m}^{2,3,5}$. However, this article concentrates on the charge carrier transport of $\mathrm{CH}_{3} \mathrm{NH}_{3} \mathrm{PbI}_{3-\mathrm{x}} \mathrm{Cl}_{\mathrm{x}}$ thin films using Hall Effect and dc-electrical conductivity measurement as a function of temperature, ranging from RT to $378 \mathrm{~K}$. The carrier concentration, mobility, excitonic effective mass, excitonic binding energy, Fermi level, grain boundary barrier height and mean free life time of charge carriers are calculated from Hall Effect study. Furthermore, activation energies in $\mathrm{CH}_{3} \mathrm{NH}_{3} \mathrm{PbI}_{3-\mathrm{x}} \mathrm{Cl}_{\mathrm{x}}$ thin films are exposed from electrical study. The effect of polarons on charge carrier dynamics and possible carrier conduction mechanism in $\mathrm{CH}_{3} \mathrm{NH}_{3} \mathrm{PbI}_{3-\mathrm{x}} \mathrm{Cl}_{\mathrm{x}}$ thin films has been discussed. Therefore, in-depth study of charge carrier transport and conduction mechanism above $\mathrm{RT}$ for $\mathrm{CH}_{3} \mathrm{NH}_{3} \mathrm{PbI}_{3-\mathrm{x}} \mathrm{Cl}_{\mathrm{x}}$ may provide a broader impact in the arena of perovskite research.

\section{Results}

Temperature dependent Hall effect study. Temperature dependent Hall voltage measurement is done at a constant magnetic field of $9.815 \mathrm{KG}$ and the variation of Hall voltage is shown in Fig. 1. From the Hall Effect study Hall mobility $\left(\mu_{H}\right)$ and carrier concentration $\left(n_{c}\right)$ have also been calculated.

From Fig. 1 it is seen that the Hall voltage is positive and increased up to a certain temperature after which it decreases all through the measured temperature range for all samples. The positive sign of Hall voltage indicates that $\mathrm{CH}_{3} \mathrm{NH}_{3} \mathrm{PbI}_{3-\mathrm{x}} \mathrm{Cl}_{\mathrm{x}}$ is a p-type material. It is reported that a lot of $\mathrm{Pb}, \mathrm{CH}_{3} \mathrm{NH}_{3}$, I and $\mathrm{Cl}$ vacancies present in the films ${ }^{17,26,27}$ as because precursor solution was prepared by dissolving $\mathrm{CH}_{3} \mathrm{NH}_{3} \mathrm{I}$ and $\mathrm{PbCl}_{2}$ at a molar ratio 3:1. However, $\mathrm{Pb}$ and $\mathrm{CH}_{3} \mathrm{NH}_{3}$ vacancies play the vital role for p-type conductivity of prepared $\mathrm{CH}_{3} \mathrm{NH}_{3} \mathrm{PbI}_{3-\mathrm{x}} \mathrm{Cl}_{\mathrm{x}}$ thin films because of the lower formation energy of $\mathrm{Pb}$ and $\mathrm{CH}_{3} \mathrm{NH}_{3}$ compared to halogen vacancies.

The temperature dependent carrier concentration (left scale) and mobility (right scale) for (a) CDC, (b) spray and (c) dipping deposite $\mathrm{CH}_{3} \mathrm{NH}_{3} \mathrm{PbI}_{3-\mathrm{x}} \mathrm{Cl}_{\mathrm{x}}$ thin films are shown in Fig. 2. The carrier concentration and mobility of dipping deposited sample is found almost half of the CDC and spray deposited samples. However, RT mobilities are found higher for all our samples than previously reported works $s^{6,14,16,19,28-32}$. Table 1 shows a comparison of RT mobilities for perovskite $\mathrm{CH}_{3} \mathrm{NH}_{3} \mathrm{PbI}_{3-\mathrm{x}} \mathrm{Cl}_{\mathrm{x}}$ obtained in different studies. It is reported that the breaking of inversion symmetry generates Rashba effect ${ }^{33}$ which enhance longitudinal optical phonon scattering by displacing the organic part or $\mathrm{Pb}$-halogen bending or stretching and limits the increase of charge-carrier mobility at room temperature.

The carrier concentration and mobility can be affected by both magnetic field and temperature but the effect of temperature is dominant. In this study, the carrier concentration of all $\mathrm{CH}_{3} \mathrm{NH}_{3} \mathrm{PbI}_{3-\mathrm{x}} \mathrm{Cl}_{\mathrm{x}}$ samples is found to increase exponentially (Fig. 2) with increasing temperature but mobility shows completely an opposite trend. Such behavior can be explained as: the presence of $\mathrm{Pb}, \mathrm{CH}_{3} \mathrm{NH}_{3}$ and halogen vacancies in mixed halide perovskite creates free dipolar polarons by inducing a rotational re-organization of organic $\mathrm{CH}_{3} \mathrm{NH}_{3}$ dipoles ${ }^{20}$; such polarons 

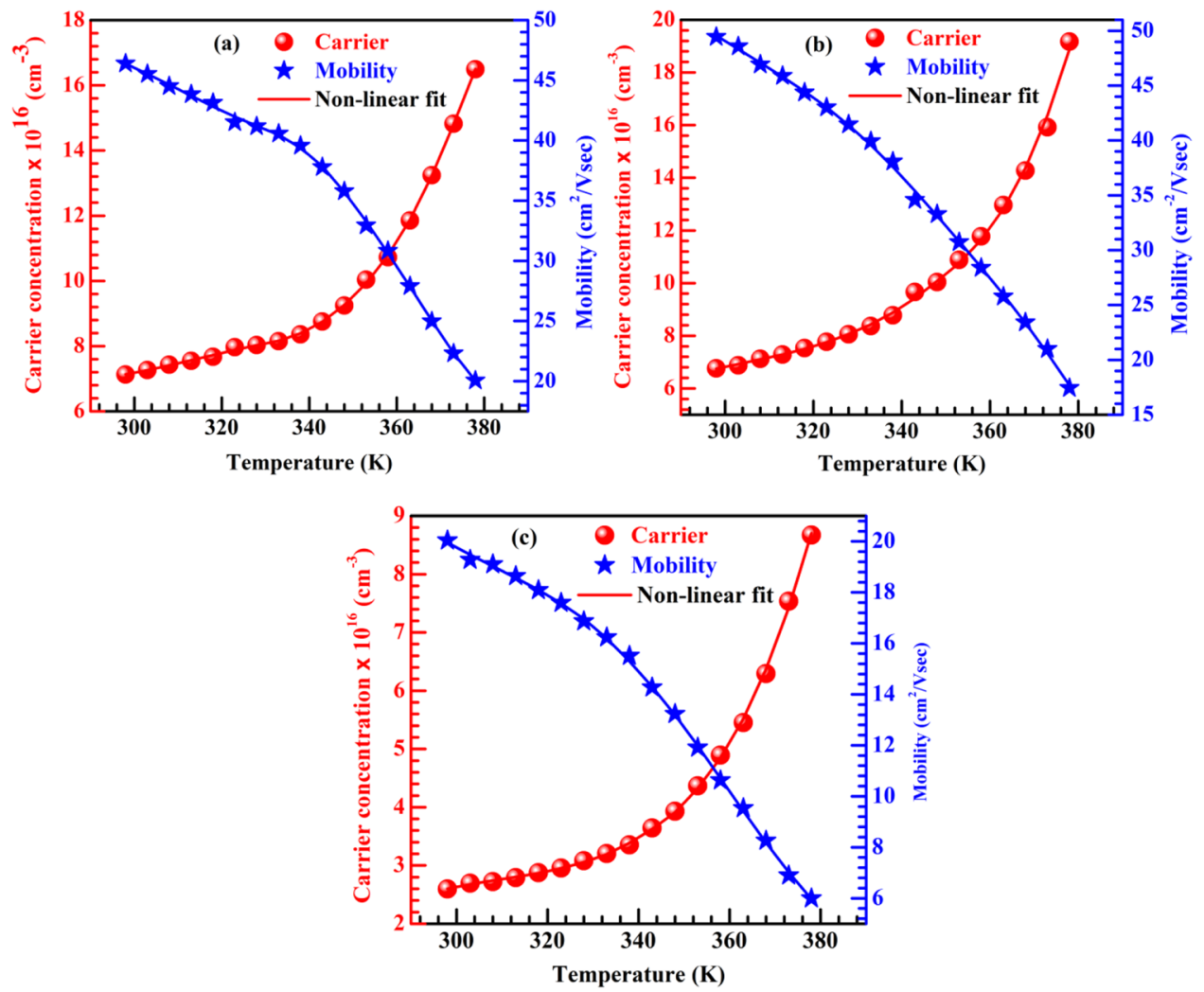

Figure 2. Charge carrier transport of $\mathrm{CH}_{3} \mathrm{NH}_{3} \mathrm{PbI}_{3-\mathrm{x}} \mathrm{Cl}_{\mathrm{x}}$. Variation of carrier concentration (left scale) and mobility (right scale) with temperature at a constant magnetic field of $9.815 \mathrm{KG}$ for (a) CDC, (b) spray and (c) dipping deposited $\mathrm{CH}_{3} \mathrm{NH}_{3} \mathrm{PbI}_{3-\mathrm{x}} \mathrm{Cl}_{\mathrm{x}}$ thin films.

\begin{tabular}{|l|l|l|l|l|}
\hline Perovskites & Measurement & $\mathbf{n}_{\mathbf{c}}\left(\mathbf{c m}^{-3}\right)$ & $\boldsymbol{\mu}_{\mathrm{H}}\left(\mathbf{c m}^{2} / \mathbf{V}\right.$-s $)$ & Ref. \\
\hline \multirow{5}{*}{$\begin{array}{l}\mathrm{CH}_{3} \mathrm{NH}_{3} \mathrm{PbI}_{3-\mathrm{x}} \mathrm{Cl}_{\mathbf{x}} \\
\text { thin films }\end{array}$} & $7.1 \times 10^{16}$ & 46 & $\begin{array}{l}\text { CDC } \\
\text { This work }\end{array}$ \\
\cline { 2 - 5 } & Hall & $6.8 \times 10^{16}$ & 49 & $\begin{array}{l}\text { Spray } \\
\text { This work }\end{array}$ \\
\cline { 2 - 5 } & Hall & $2.6 \times 10^{16}$ & 20 & $\begin{array}{l}\text { Dipping } \\
\text { This work }\end{array}$ \\
\cline { 2 - 5 } & PLQ & - & 2.1 & 14 \\
\cline { 2 - 5 } & THz & - & 11.6 & 6 \\
\cline { 2 - 5 } & THz & $1.0 \times 10^{15}$ & 33 & 28 \\
\cline { 2 - 5 } & THz & - & 27 & 29 \\
\cline { 2 - 5 } & Microwave & & 27 & 30 \\
\hline \multirow{5}{*}{$\begin{array}{c}\mathrm{CH}_{3} \mathrm{NH}_{3} \mathrm{PbI}_{3} \\
\text { single } \mathrm{crystals}_{5}\end{array}$} & Hall & $(9 \pm 2) \times 10^{9}$ & 105 & 34 \\
\cline { 2 - 5 } & Hall & $(1.0-$ & $80-95$ & 25 \\
\hline \multirow{5}{*}{$\begin{array}{l}\mathrm{CH}_{3} \mathrm{NH}_{3} \mathrm{PbI}_{3} \\
\text { thin films }\end{array}$} & THz & - & 8 & 6 \\
\cline { 2 - 5 } & THz & & 35 & 19 \\
\cline { 2 - 5 } & THz & - & 20 & 31 \\
\cline { 2 - 5 } & TOF & - & 0.25 & 16 \\
\cline { 2 - 5 } & Microwave & - & 30 & 30 \\
\cline { 2 - 5 } & Microwave & - & 29 & 32 \\
\hline
\end{tabular}

Table 1. The RT Hall carrier concentration $\left(\mathrm{n}_{\mathrm{c}}\right)$ and mobility $\left(\mu_{\mathrm{H}}\right)$ of CDC, spray and dipping deposited $\mathrm{CH}_{3} \mathrm{NH}_{3} \mathrm{PbI}_{3-\mathrm{x}} \mathrm{Cl}_{\mathrm{x}}$ thin films.

can migrate between the inorganic site of perovskite structure and lower the electron-hole recombination. Furthermore, sub-lattice thermal vibrations of inorganic octahedral have also an effect on carrier concentration and mobility in perovskite samples. Both the reorientation of organic site and sub-lattice thermal vibration enhance 


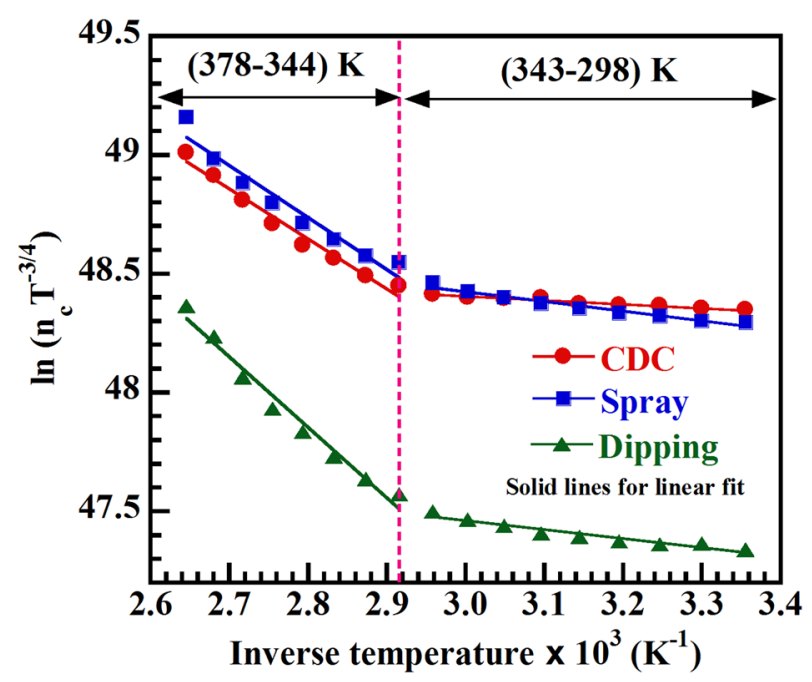

Figure 3. Diagram for calculating acceptor ionization energy. $\ln \left(\mathrm{n}_{\mathrm{c}} \mathrm{T}^{-3 / 4}\right)$ vs inverse temperature graph for $\mathrm{CDC}$, spray and dipping deposited $\mathrm{CH}_{3} \mathrm{NH}_{3} \mathrm{PbI}_{3-\mathrm{x}} \mathrm{Cl}_{\mathrm{x}}$ thin films.

the localized charge carriers which introduce a dynamic force for the movement of charges with increasing temperature. Therefore, a polarization potential of polaron originated by enhanced localization suppresses carrier velocity and reduce the mobility of $\mathrm{CH}_{3} \mathrm{NH}_{3} \mathrm{PbI}_{3-\mathrm{x}} \mathrm{Cl}_{\mathrm{x}}$ samples. Such a decrease of mobility with increasing temperature is reported ${ }^{19}$ measured by ultrafast spectroscopic method at temperature range $-200{ }^{\circ} \mathrm{C}$ to $100{ }^{\circ} \mathrm{C}$.

Effective mass, excitonic binding energy and Fermi level calculation. The acceptor ionization energy, Fermi level and effective mass of charge carriers have been calculated from the temperature dependent Hall voltage measurement. The temperature dependent carrier concentration in the presence of a constant magnetic field can be represented by following equations,

$$
\mathrm{n}_{\mathrm{c}}=\left(\mathrm{p}_{0} \mathrm{~N}_{\mathrm{a}}\right)^{\frac{1}{2}} \exp \left(-\frac{\mathrm{E}_{\mathrm{a}}}{2 \mathrm{~K}_{\mathrm{B}} \mathrm{T}}\right)
$$

and

$$
\mathrm{p}_{0}=2\left(\frac{2 \pi \mathrm{m}_{\mathrm{h}}^{*} \mathrm{~K}_{\mathrm{B}} \mathrm{T}}{\hbar^{2}}\right)^{\frac{3}{2}}
$$

where $E_{a}$ is the acceptor ionization energy, $N_{a}$ is the acceptor density, $m_{h}^{*}$ is the effective mass of hole, $T$ is the absolute temperature, $K_{B}$ is the Boltzmann constant and $\hbar$ is the reduced Planck constant. The value of $E_{a}$ can be obtained from the slope of $\ln \left(n_{c} T^{-\frac{3}{4}}\right)$ vs. 1/T graph (Fig. 3). From figure it is clear that the variation of carrier concentration with temperature can be defined by two discrete temperature regions (TR): TR-I (298-343) K and TR-II (344-378) K. In TR-II, the values of $\ln \left(\mathrm{n}_{\mathrm{c}} \mathrm{T}^{-\frac{3}{4}}\right)$ decrease linearly with inverse temperature, whereas, in TR-I, it decreases monotonically with lower slope compared to TR-II. The effective mass of hole $\mathrm{m}_{\mathrm{h}}^{*}$ can be found out using $\mathrm{E}_{\mathrm{a}}$ as,

$$
\mathrm{E}_{\mathrm{a}}=\frac{\mathrm{e}^{4} \mathrm{~m}_{\mathrm{h}}^{*}}{2\left(4 \pi \varepsilon \varepsilon_{0} \hbar\right)^{2}}
$$

where $\varepsilon$ is the dielectric constant of the material and $\varepsilon_{0}$ is the permittivity of free space. Several research groups used dielectric constant $\varepsilon=5.6$ to 25.7 (for high to low frequency) and excitonic effective mass $\mu^{*}=0.1 \mathrm{~m}_{\mathrm{e}}$ for calculating excitonic binding energy of perovskite. However, in this study $\varepsilon=9$ has been used for calculating $\mathrm{m}_{\mathrm{h}}^{*}$ according to hydrogenic model ${ }^{35}$. The values of $\mathrm{m}_{\mathrm{h}}^{*}$ are estimated to $0.16 \mathrm{~m}_{\mathrm{e}}, 0.42 \mathrm{~m}_{\mathrm{e}}, 0.38 \mathrm{~m}_{\mathrm{e}}\left(\mathrm{m}_{\mathrm{e}}\right.$ is the rest mass of electron) in the TR-I and $2.16 \mathrm{~m}_{\mathrm{e}}, 2.23 \mathrm{~m}_{\mathrm{e}}, 3.04 \mathrm{~m}_{\mathrm{e}}$ in the TR-II for CDC, spray and dipping deposited samples, respectively. The estimated $\mathrm{m}_{\mathrm{h}}^{*}$ is found in good agreement with recently reported values ${ }^{36,37}$. Taking the effective mass of electron $\mathrm{m}_{\mathrm{e}}^{*}=0.21 \mathrm{~m}_{\mathrm{e}}$ from theoretical calculations ${ }^{38}$, the excitonic effective mass $\mu^{*}$ is estimated to $(0.090-0.196) \mathrm{m}_{\mathrm{e}}$ using equation, $1 / \mu^{*}=1 / \mathrm{m}_{\mathrm{e}}^{*}+1 / \mathrm{m}_{\mathrm{b}}^{*}$ and tabulated in Table 2 . The estimated $\mu^{*}$ in TR-I is close to $\sim 0.104 \mathrm{~m}_{\mathrm{e}}^{35}$, found for tetragonal phase $(\geq 145 \mathrm{~K})$. However, $\mu^{*}$ in TR-II is found high because of non-parabolic nature of valance bands in $\mathrm{CH}_{3} \mathrm{NH}_{3} \mathrm{PbI}_{3-\mathrm{x}} \mathrm{Cl}_{\mathrm{x}}$. Theoretical study ${ }^{39}$ suggested that lead vacancies diminish antibonding atomic orbital overlap resulting in flatten of valance bands. Moreover, polaronic effect ${ }^{40}$ and strong hydrogen bonding due to van-der-Waals interactions ${ }^{39}$ may also increase $\mu^{*}$.

The excitonic binding energy, $\mathrm{E}_{\mathrm{b}}$ of all perovskite samples has been calculated using the equation, 


\begin{tabular}{|c|c|c|c|c|c|c|c|c|c|c|}
\hline \multirow[b]{2}{*}{ Samples } & \multicolumn{2}{|c|}{$E_{a}(e V)$} & \multicolumn{2}{|c|}{$\begin{array}{l}\mathrm{N}_{\mathrm{a}} \times 10^{16} \\
\left(\mathrm{~cm}^{-3}\right)\end{array}$} & \multicolumn{2}{|l|}{$E_{F}(e V)$} & \multicolumn{2}{|l|}{$\mu^{*} / \mathbf{m}_{e}$} & \multicolumn{2}{|c|}{$\mathrm{E}_{\mathrm{b}}(\mathrm{meV})$} \\
\hline & TR-I & TR-II & TR-I & TR-II & TR-I & TR-II & TR-I & TR-II & TR-I & TR-II \\
\hline CDC & 0.028 & 0.364 & 2.00 & 6.34 & -0.014 & -0.182 & 0.090 & 0.191 & 15 & 32 \\
\hline Spray & 0.071 & 0.378 & 3.80 & 11.3 & -0.035 & -0.189 & 0.140 & 0.192 & 24 & 32 \\
\hline Dipping & 0.065 & 0.512 & 0.19 & 96.7 & -0.032 & -0.256 & 0.135 & 0.196 & 23 & 33 \\
\hline
\end{tabular}

Table 2. The acceptor ionization energy $\left(\mathrm{E}_{\mathrm{a}}\right)$, acceptor density $\left(\mathrm{N}_{\mathrm{a}}\right)$, Fermi level $\left(\mathrm{E}_{\mathrm{F}}\right)$, excitonic reduced effective mass $\left(\mu^{*}\right)$ and excitonic binding energy $\left(\mathrm{E}_{\mathrm{b}}\right)$ of charge carrier for CDC, spray and dipping deposited $\mathrm{CH}_{3} \mathrm{NH}_{3} \mathrm{PbI}_{3-\mathrm{x}} \mathrm{Cl}_{\mathrm{x}}$ thin films for TR-I (298-343) $\mathrm{K}$ and TR-II (344-378) K.

$$
\mathrm{E}_{\mathrm{b}}=\frac{\mathrm{m}_{\mathrm{e}} \mathrm{e}^{4}}{2\left(4 \pi \epsilon_{0} \varepsilon \hbar\right)^{2}} \frac{\mu^{*}}{\mathrm{~m}_{\mathrm{e}}}(\mathrm{eV}) \approx 13.56 \frac{\mu^{*}}{\mathrm{~m}_{\mathrm{e}}} \frac{1}{\varepsilon^{2}}(\mathrm{eV})
$$

The excitonic binding energy is found (15-24) meV for TR-I and (32-33) meV for TR-II, which is well consistent according to Wannier-Mott hydrogenic model. This variation of $\mathrm{E}_{\mathrm{b}}$ in TR-I and TR-II is due to temperature dependent polaronic effect of $\mathrm{CH}_{3} \mathrm{NH}_{3} \mathrm{PbI}_{3-\mathrm{x}} \mathrm{Cl}_{\mathrm{x}}$. The extending radius of the lowest bound state $\mathrm{r}^{*}$ is calculated to ascertain the nature of excitons in $\mathrm{CH}_{3} \mathrm{NH}_{3} \mathrm{PbI}_{3-\mathrm{x}} \mathrm{Cl}_{\mathrm{x}}$ using the equation, $\mathrm{r}^{*}=\varepsilon\left(\mathrm{m}_{\mathrm{e}} / \mu^{*}\right) \mathrm{r}_{\mathrm{b}}$, where, $\mathrm{r}_{\mathrm{b}}$ is the Bohr radius. The $\mathrm{r}^{*}$ is estimated to $5.29 \mathrm{~nm}, 3.40 \mathrm{~nm}, 3.52 \mathrm{~nm}$ in TR-I and $2.49 \mathrm{~nm}, 2.48 \mathrm{~nm}, 2.43 \mathrm{~nm}$ in TR-II for CDC, spray and dipping deposited samples. The value of $\mathrm{r}^{*}$ is larger than the lattice constants (either cubic or tetragonal) of $\mathrm{CH}_{3} \mathrm{NH}_{3} \mathrm{PbI}_{3-\mathrm{x}} \mathrm{Cl}_{\mathrm{x}}$ indicating that the exciton is weak and likely to be Mott-Wannier type.

The position of Fermi level $\mathrm{E}_{\mathrm{F}}$ can be determined by knowing the value of $\mathrm{E}_{\mathrm{a}}, \mathrm{N}_{\mathrm{a}}$ and $m_{h}^{*}$ of the following equation

$$
\mathrm{E}_{\mathrm{F}}=-\frac{1}{2} \mathrm{E}_{\mathrm{a}}+\frac{1}{2}\left(\mathrm{~K}_{\mathrm{B}} \mathrm{T}\right) \ln \left[\frac{\mathrm{N}_{\mathrm{a}} \mathrm{h}^{3}}{2\left(2 \pi m_{\mathrm{h}}^{*} \mathrm{~K}_{\mathrm{B}} \mathrm{T}\right)^{\frac{3}{2}}}\right]
$$

The values of $E_{a}, N_{a}$ and $E_{F}$ for both higher and lower temperature regions are tabulated in Table 2. The parameters $\mathrm{n}_{\mathrm{c}}$ and $\mathrm{N}_{\mathrm{a}}$ are not equal but vary with temperature and film processing methods as well, indicates $\mathrm{CH}_{3} \mathrm{NH}_{3} \mathrm{PbI}_{3-\mathrm{x}} \mathrm{Cl}_{\mathrm{x}}$ is very sensitive to environment, chemical composition, growth parameters etc. The Fermi energy is found negative means $\mathrm{E}_{\mathrm{F}}$ lies below the acceptor level.

Grain boundary parameters and grain size calculations. The transport properties of a polycrystalline semiconductor are generally influenced by grain boundary effect. According to grain boundary trapping model $^{41}$, the trapping states create a depletion region in the grain and a potential barrier at the interface. In a semiconductor sample the relation between charge carrier mobility and grain boundary barrier height can be expressed as

$$
\begin{gathered}
\mu_{\mathrm{h}}=\mu_{0} \mathrm{~T}^{-\frac{1}{2}} \exp \left(\frac{-\phi_{\mathrm{b}}}{\mathrm{K}_{\mathrm{B}} \mathrm{T}}\right) \text { with } \\
\mu_{0}=\frac{e \zeta}{\left(8 \pi m_{\mathrm{h}}^{*} \mathrm{~K}_{\mathrm{B}}\right)^{\frac{1}{2}}},
\end{gathered}
$$

where, $\phi_{\mathrm{b}}$ is the grain boundary barrier height and $\zeta$ is the grain size. The slop of $\ln \left(\mu_{\mathrm{h}} \mathrm{T}^{1 / 2}\right)$ vs $1 / \mathrm{T}$ graph (Fig. 4) gives the barrier height $\phi_{\mathrm{b}}$ and intercept will provide grain size $\zeta$.

The barrier height and grain size of all samples have been estimated for two different temperature regions (TR-I, TR-II) and tabulated in Table 3. From table it is clearly seen that the formation of bigger grain size is favorable at low temperature (TR-I) for mixed halide perovskites.

Mean free path and mean free time calculations. According to conventional Drude-Sommerfeld model, the carrier mean free path $\left(\mathrm{L}_{\mathrm{m}}\right)$ and mean free time $\left(\tau_{\mathrm{m}}\right)$ in $\mathrm{CH}_{3} \mathrm{NH}_{3} \mathrm{PbI}_{3-\mathrm{x}} \mathrm{Cl}_{\mathrm{x}}$ thin films can be calculated from the following equations

$$
\begin{gathered}
\mathrm{L}_{\mathrm{m}}=\mu_{\mathrm{H}} \frac{\left(3 \mathrm{~m}_{\mathrm{h}}^{*} \mathrm{~K}_{\mathrm{B}} \mathrm{T}\right)^{\frac{1}{2}}}{\mathrm{e}} \\
\tau_{\mathrm{m}}=\frac{\mu_{\mathrm{H}} \mathrm{m}_{\mathrm{h}}^{*}}{\mathrm{e}}
\end{gathered}
$$

The variation of $\mathrm{L}_{\mathrm{m}}$ and $\tau_{\mathrm{m}}$ with temperature for $\mathrm{CDC}$, spray and dipping deposited $\mathrm{CH}_{3} \mathrm{NH}_{3} \mathrm{PbI}_{3-\mathrm{x}} \mathrm{Cl}_{\mathrm{x}}$ thin films are given in Fig. 5. 


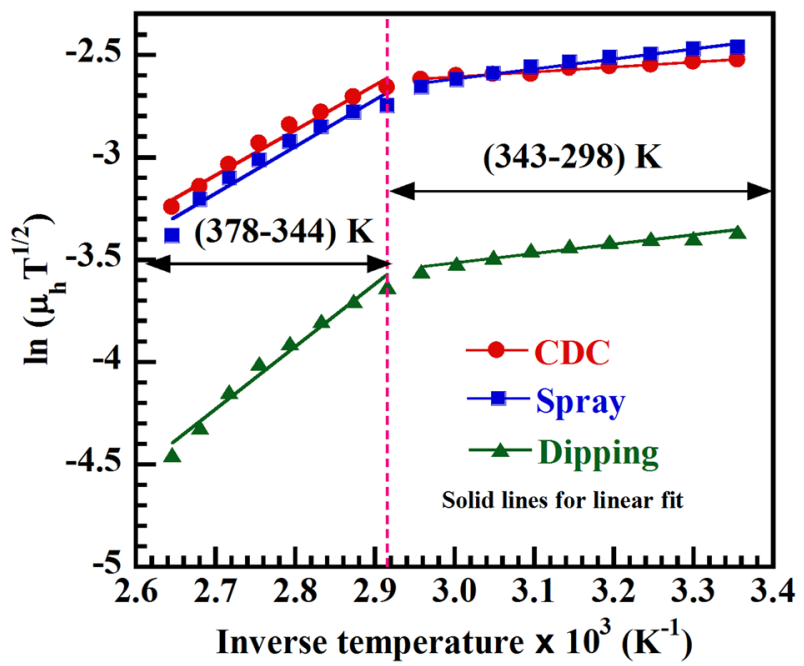

Figure 4. Figure for calculating grain boundary parameters. $\ln \left(\mu_{\mathrm{h}} \mathrm{T}^{1 / 2}\right)$ vs $1 / \mathrm{T}$ graph for CDC, spray and dipping deposited $\mathrm{CH}_{3} \mathrm{NH}_{3} \mathrm{PbI}_{3-\mathrm{x}} \mathrm{Cl}_{\mathrm{x}}$ thin films.

\begin{tabular}{|c|c|c|c|c|c|c|c|c|c|c|c|}
\hline \multirow[b]{2}{*}{ Samples } & \multicolumn{2}{|l|}{$\phi_{\mathrm{b}}(\mathrm{eV})$} & \multicolumn{2}{|c|}{$\zeta(\mathbf{n m})$} & \multicolumn{2}{|c|}{$\begin{array}{l}\left(\mathbf{L}_{\mathbf{m}}\right)_{\text {avg }} \times 10^{-09} \\
(\mathbf{m})\end{array}$} & \multicolumn{2}{|c|}{$\begin{array}{l}\left(\tau_{\mathrm{m}}\right)_{\mathrm{avg}} \times 10^{-14} \\
(\mathrm{~s})\end{array}$} & \multicolumn{3}{|c|}{$\Delta \mathrm{E}(\mathrm{eV})$} \\
\hline & TR-I & TR-II & TR-I & TR-II & \begin{tabular}{|l|} 
TR-I \\
\end{tabular} & TR-II & TR-I & TR-II & $\Delta \mathrm{E}_{\mathrm{I}}$ & $\Delta \mathrm{E}_{\mathrm{II}}$ & $\Delta \mathrm{E}_{\text {III }}$ \\
\hline CDC & -0.020 & -0.189 & 3.71 & 0.40 & 1.19 & 3.11 & 0.40 & 3.58 & -0.92 & 0.44 & \begin{tabular}{|l|} 
\\
\end{tabular} \\
\hline Spray & -0.042 & -0.196 & 3.59 & 0.35 & 1.96 & 2.92 & 1.06 & 3.40 & -1.39 & 0.51 & 0.86 \\
\hline Dipping & -0.039 & -0.264 & \begin{tabular}{|l|}
1.98 \\
\end{tabular} & 0.10 & 0.76 & 1.28 & 0.39 & 1.74 & -0.29 & 0.47 & \begin{tabular}{|l|}
0.57 \\
\end{tabular} \\
\hline
\end{tabular}

Table 3. Grain boundary barrier height $\left(\phi_{\mathrm{b}}\right)$, grain size $(\zeta)$, mean free path $\left(\mathrm{L}_{\mathrm{m}}\right)$, mean free life time $\left(\tau_{\mathrm{m}}\right)$ and activation energies $(\triangle \mathrm{E})$ for $\mathrm{CDC}$, spray and dipping deposited $\mathrm{CH}_{3} \mathrm{NH}_{3} \mathrm{PbI}_{3-\mathrm{x}} \mathrm{Cl}_{\mathrm{x}}$ thin films.

From figures it is seen that both $\mathrm{L}_{\mathrm{m}}$ and $\tau_{\mathrm{m}}$ are lower at TR-I compared to TR-II. The magnitudes of $\mathrm{L}_{\mathrm{m}}$ and $\tau_{\mathrm{m}}$ decrease with the increase of temperature except a sudden jump at around $340 \mathrm{~K}$. The polaronic effect originated from rotational re-organization of $\mathrm{CH}_{3} \mathrm{NH}_{3}$ dipoles enhances trap assisted recombination with increasing temperature which reduces the carrier mean free path and mean free life time.

In the mixed halide perovskite, the transition from tetragonal to cubic phase occurs at temperature $\sim 330 \mathrm{~K}^{19,42}$ due to the tilted inorganic $\mathrm{PbI}_{6}$ octahedral and disparity of organic $\mathrm{CH}_{3} \mathrm{~N} \mathrm{H}_{3}^{+}$rotation. Such phase transition can modify the physical properties of mixed halide perovskites, though it does not cause remarkable change in optical and photovoltaic properties ${ }^{43}$. Recently, tetragonal to cubic phase transition is associated with the relative strength of the metal-halogen and hydrogen bonds as reported ${ }^{44}$. In our study, during the temperature dependent Hall measurement we have applied a magnetic field of $\sim 1 \mathrm{~T}$. This magnetic energy shifted the tetragonal to cubic phase transition at slightly higher temperature at (340-344) K.

Conduction mechanisms and activation energies. The electrical conduction process in $\mathrm{CH}_{3} \mathrm{NH}_{3} \mathrm{PbI}_{3-\mathrm{x}} \mathrm{Cl}_{\mathrm{x}}$ is rather complex. It is strongly dependent on temperature, vacancies or interstitial defects and activation energies of the materials. In general, $\mathrm{CH}_{3} \mathrm{NH}_{3} \mathrm{PbI}_{3-\mathrm{x}} \mathrm{Cl}_{\mathrm{x}}$ includes $\mathrm{Pb}, \mathrm{CH}_{3} \mathrm{NH}_{3}$ and halogen vacancies as suggested from theoretical and experimental studies ${ }^{45,46}$. The low energy vacancies create a rotational reorganization of organic $\mathrm{CH}_{3} \mathrm{NH}_{3}$ dipoles resulting in free dipolar polarons in mixed halide perovskite ${ }^{20}$. Eames et al. ${ }^{45}$ proposed that these vacancies migrate from one site to the neighboring site due to low activation energy. They found activation energies involved $0.58 \mathrm{eV}$ and $0.84 \mathrm{eV}$ for migrating $\mathrm{I}^{-}$and $\mathrm{CH}_{3} \mathrm{~N} \mathrm{H}_{3}^{+}$vacancies, respectively. Futscher et al. ${ }^{47}$ also reported that the predicted activation energies for migration of $\mathrm{I}^{-}$and $\mathrm{CH}_{3} \mathrm{~N} \mathrm{H}_{3}^{+}$ are (0.08-0.58) eV and (0.46-1.12) eV, respectively. Besides, grain boundary effect has an influence on carrier transport and the activation energies $(0.18-0.27) \mathrm{eV}$ were predicted for different grain size above $260 \mathrm{~K}^{48}$. In Fig. 6, it is clearly seen that there are three temperature regions where carriers are conducted through different conduction mechanisms. For further clarification, the activation energy was also calculated by Arrhenius equation which contains three separate activation energy terms,

$$
\sigma_{\mathrm{dc}}=\sigma_{\mathrm{I}} \exp \left(\frac{-\Delta \mathrm{E}_{\mathrm{I}}}{\mathrm{K}_{\mathrm{B}} \mathrm{T}}\right)+\sigma_{\mathrm{II}} \exp \left(\frac{-\Delta \mathrm{E}_{\mathrm{II}}}{\mathrm{K}_{\mathrm{B}} \mathrm{T}}\right)+\sigma_{\mathrm{III}} \exp \left(\frac{-\Delta \mathrm{E}_{\mathrm{III}}}{\mathrm{K}_{\mathrm{B}} \mathrm{T}}\right)
$$



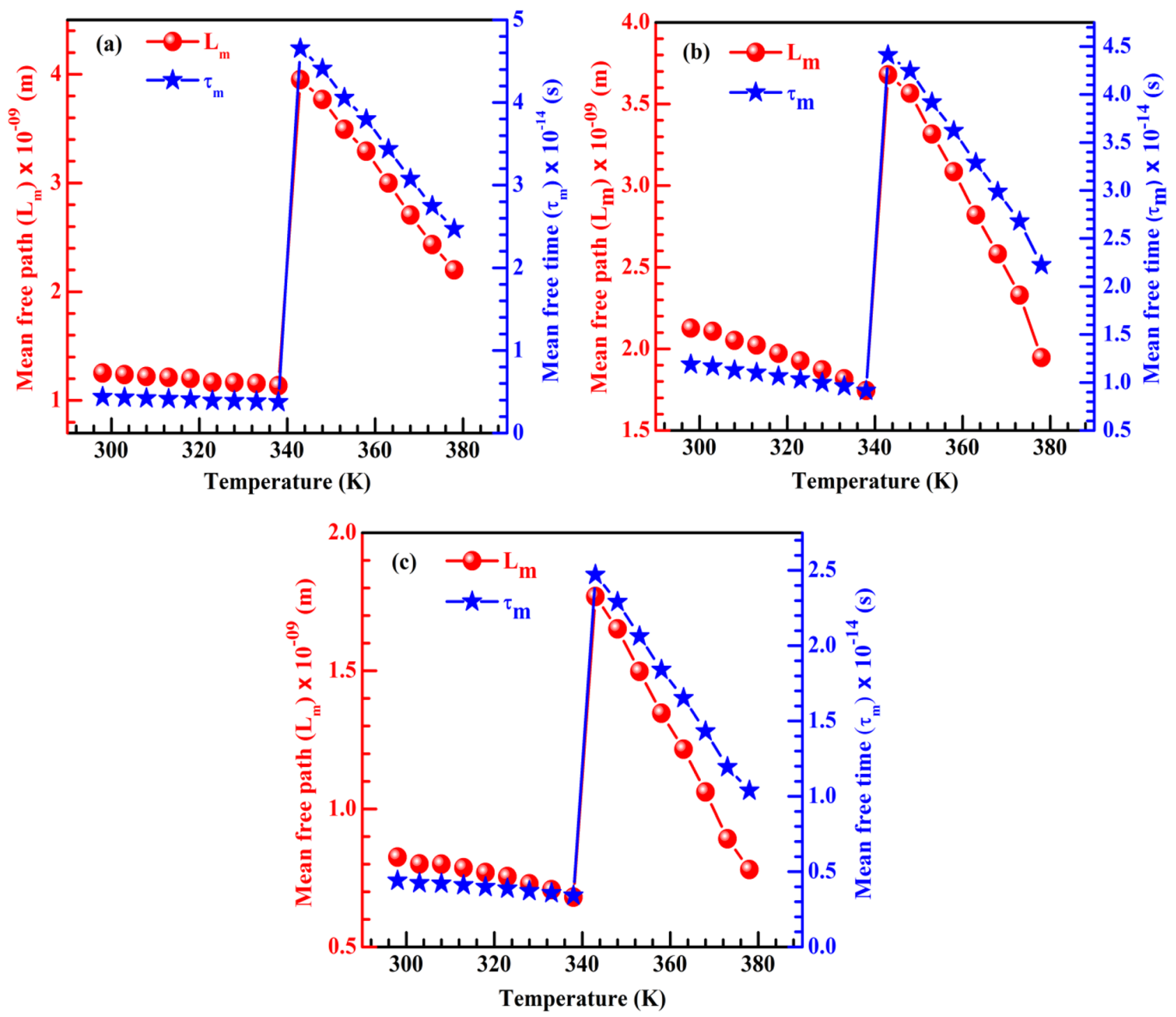

Figure 5. Mean free path and mean free time of $\mathrm{CH}_{3} \mathrm{NH}_{3} \mathrm{PbI}_{3-\mathrm{x}} \mathrm{Cl}_{\mathrm{x}}$. Mean free path and mean free time at different temperature region for (a) CDC, (b) spray and (c) dipping deposited $\mathrm{CH}_{3} \mathrm{NH}_{3} \mathrm{PbI}_{3-\mathrm{x}} \mathrm{Cl}_{\mathrm{x}}$ thin films.

where, $\mathrm{K}_{\mathrm{B}}$ is the Boltzmann constant, $\mathrm{T}$ is the absolute temperature, $\sigma_{\mathrm{I}}, \sigma_{\mathrm{II}}$ and $\sigma_{\mathrm{III}}$ are pre-exponential factors and $\Delta \mathrm{E}_{\mathrm{I}}, \Delta \mathrm{E}_{\mathrm{II}}$ and $\Delta \mathrm{E}_{\mathrm{III}}$ are activation energies for region I, II and III, respectively. From the slope of ln $\sigma$ vs $1000 / \mathrm{T}$ plot (inset of Fig. 6), the activation energies were calculated and tabulated in Table 3.

From Fig. 6 , it is seen that dc-electrical conductivity $\left(\sigma_{\mathrm{dc}}\right)$ decreases with increasing temperature in region I (294-317) K. The initial decrease is caused by the strong interactions in between organic-inorganic part and rotational disorder of methylammonium cation within perovskite structure. In addition, longitudinal optical phonon scattering may also decrease the conductivity with temperature in region $\mathrm{I}$. The activation energy $\Delta \mathrm{E}_{\mathrm{I}}($ Table 3 ) is found negative in region I, suggesting the Fermi level is pinned to the valance band of all samples. In region II $(318-357) \mathrm{K}$, the dc-electrical conductivity increase slowly with increasing temperature and $\Delta \mathrm{E}_{\mathrm{II}}=0.44,0.51$, $0.47 \mathrm{eV}$ for $\mathrm{CDC}$, spray and dipping deposited samples respectively, which indicates the migration of $\mathrm{I}^{-}$vacan- $^{-}$ cies to $\mathrm{PbI}_{6}$ octahedron edge ${ }^{45-47}$. In region III $(358-378) \mathrm{K}, \sigma_{\mathrm{dc}}$ increases rapidly and $\Delta \mathrm{E}_{\mathrm{III}}{ }^{>} \Delta \mathrm{E}_{\mathrm{II}}$. The activation energies $\Delta \mathrm{E}_{\mathrm{III}}$ are found close to $0.84 \mathrm{eV}$ for $\mathrm{CDC}$ and spray deposited and $\Delta \mathrm{E}_{\mathrm{III}}=0.57 \mathrm{eV}$ for dipping deposited samples. The rapid increase of $\sigma_{\mathrm{dc}}$ in region III occurs because of diffusion or migration of $\mathrm{CH}_{3} \mathrm{~N} \mathrm{H}_{3}^{+}$in addition to $\mathrm{I}^{-}$vacancies to $\mathrm{PbI}_{6}$ octahedra or neighbor central vacant site ${ }^{45-47}$. Therefore, the conduction processes are attributed to the migration of $\mathrm{I}^{-}$and $\mathrm{CH}_{3} \mathrm{~N} \mathrm{H}_{3}^{+}$suggesting the existence of ionic transport in $\mathrm{CH}_{3} \mathrm{NH}_{3} \mathrm{PbI}_{3-\mathrm{x}} \mathrm{Cl}_{\mathrm{x}}$. Moreover, the concentrations of charge carriers (majority holes) which are activated with acceptor ionization energy $\left(\mathrm{E}_{\mathrm{a}}\right)$ favorable for the transport across grain boundaries of $\mathrm{CH}_{3} \mathrm{NH}_{3} \mathrm{PbI}_{3-\mathrm{x}} \mathrm{Cl}_{\mathrm{x}}$ samples. 


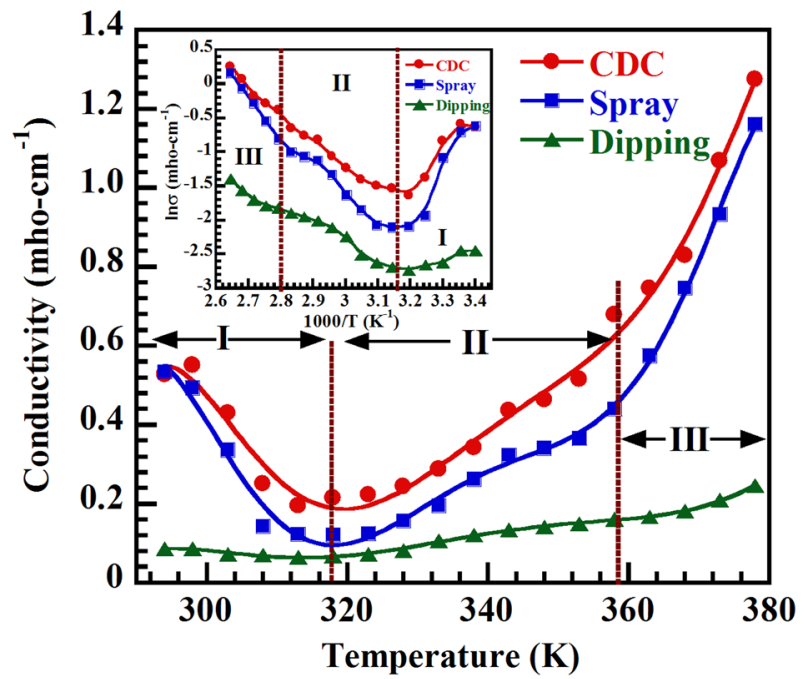

Figure 6. Electrical properties of $\mathrm{CH}_{3} \mathrm{NH}_{3} \mathrm{PbI}_{3-\mathrm{x}} \mathrm{Cl}_{\mathrm{x}}$. Temperature dependent dc-electrical conductivity of $\mathrm{CH}_{3} \mathrm{NH}_{3} \mathrm{PbI}_{3-\mathrm{x}} \mathrm{Cl}_{\mathrm{x}}$ thin films showing three distinct regions. Inset shows the variation of ln $\sigma$ with 1000/T graph for calculating activation energy.

\section{Discussion}

In summary, the charge carrier conduction mechanism of $\mathrm{CH}_{3} \mathrm{NH}_{3} \mathrm{PbI}_{3-\mathrm{x}} \mathrm{Cl}_{\mathrm{x}}$ thin films have been evaluated as a function of temperature ranging from room temperature to $378 \mathrm{~K}$. Hall measurement study confirms that the prepared $\mathrm{CH}_{3} \mathrm{NH}_{3} \mathrm{PbI}_{3-\mathrm{x}} \mathrm{Cl}_{\mathrm{x}}$ films are p-type semiconductor with carrier concentration of the order of $\sim 10^{16} \mathrm{~cm}^{-3}$. The carrier mobility found to decrease with increasing temperature due to polaronic effect. At RT, the mobilities for CDC, spray and dipping deposited samples are 46,49 and $20 \mathrm{~cm}^{2} \mathrm{~V}^{-1} \mathrm{~s}^{-1}$, respectively. The excitonic effective mass $\left(\mu^{*}\right)$ is estimated to be $(0.090-0.196) \mathrm{m}_{\mathrm{e}}$ and excitonic binding energy $\left(\mathrm{E}_{\mathrm{b}}\right)$ varies from (15-33) meV, suggesting Mott-Wannier type exciton. Additionally, the grain boundary barrier height, mean free path and mean free life time of charge carriers have also been evaluated. Electrical study reveals that multi-conduction processes are involved in $\mathrm{CH}_{3} \mathrm{NH}_{3} \mathrm{PbI}_{3-\mathrm{x}} \mathrm{Cl}_{\mathrm{x}}$, which is governed by the migration of vacancies, vacancy-assisted diffusion of mobile ions and accumulation of holes across grain boundaries.

\section{Methods}

Synthesis. Lead halide perovskite solution for fabricating $\mathrm{CH}_{3} \mathrm{NH}_{3} \mathrm{PbI}_{3-\mathrm{x}} \mathrm{Cl}_{\mathrm{x}}$ thin films was prepared using the following procedure. Methylamine $\left(\mathrm{CH}_{3} \mathrm{NH}_{2}\right)$ solution was mixed with hydroiodic acid and ethanol at room temperature. The solution was perturbed continuously by stirring with a magnetic stirrer at a constant speed in an ice bath for $2 \mathrm{~h}$. The color of $\mathrm{CH}_{3} \mathrm{NH}_{3} \mathrm{I}$ solution transforms from red to transparent and heated at $100^{\circ} \mathrm{C}$ for $4 \mathrm{~h}$ in a furnace to achieve white-colored $\mathrm{CH}_{3} \mathrm{NH}_{3} \mathrm{I}$ powder. Finally, $\mathrm{CH}_{3} \mathrm{NH}_{3} \mathrm{I}$ and lead(II) chloride powders were dissolved in anhydrous N,Ndimethylformamide at a molar ratio 3:1 to achieve a mixed halide perovskite precursor solution.

$\mathrm{CH}_{3} \mathrm{NH}_{3} \mathrm{PbI}_{3-\mathrm{x}} \mathrm{Cl}_{\mathrm{x}}$ thin films have been fabricated at ambient atmosphere by three different methods. These methods are (a) Chemical dip-coating (CDC) (b) Spray pyrolysis (spray) and (c) Repeated dipping-withdrawing (dipping). The details of preparing $\mathrm{CH}_{3} \mathrm{NH}_{3} \mathrm{PbI}_{3-\mathrm{x}} \mathrm{Cl}_{\mathrm{x}}$ solution and different steps which have been made in these methods to deposit $\mathrm{CH}_{3} \mathrm{NH}_{3} \mathrm{PbI}_{3-\mathrm{x}} \mathrm{Cl}_{\mathrm{x}}$ thin films have been reported elsewhere ${ }^{2,3,5}$.

Characterization. Temperature dependent Hall voltage was measured at constant magnetic field of 9.815 KG using the conventional van-der-Pauw method. The magnetic field used for the study of Hall Effect was provided by electromagnets designed and produced by Newport instruments Ltd. England. The circuit arrangement for temperature dependent Hall Effect measurement is shown in Fig. 1S. A dc voltage from the power supply unit was applied in order to flow the sample current through the specimen. Current and voltages were measured by a digital electrometer and a digital multi-meter. A voltage stabilizer was used so that a steady supply of current without fluctuation was maintained through the magnet. A special designed heater was used to vary temperature. The variation of temperature is controlled by a variac and measured by a chromel-alumel thermocouple connected with a digital multi-meter.

The resistivity of all samples was measured by van-der-Pauw method. Experimental setup of the van-darPauw's specimen to measure the resistivity with varying temperature is shown in Fig. $2 \mathrm{~S}$. The voltage and current of all samples were measured for different temperatures. The sample is fixed to a sample holder which is placed on a specially designed heater to vary temperature. The conductivity and activation energies of prepared samples have been calculated using resistivity data. The experimental details of temperature dependent Hall Effect measurement and resistivity measurement are shown in supplementary section. 
Received: 20 November 2020; Accepted: 30 April 2021

Published online: 24 May 2021

\section{References}

1. NREL efficiency chart. Available online: https://www.nrel.gov/pv/assets/pdfs/best-research-cell-efficiencies.20200104.pdf.

2. Karim, A. M. M. T. et al. Multi-color excitonic emissions in chemical dip-coated organolead mixed-halide perovskite. Chem. Sel. 3, 6525-6530 (2018)

3. Karim, A. M. M. T. et al. Solution-processed mixed halide $\mathrm{CH}_{3} \mathrm{NH}_{3} \mathrm{PbI}_{3-\mathrm{x}} \mathrm{Cl}_{\mathrm{x}}$ thin films prepared by repeated dip coating. J. Mater. Sci. 54, 11818-11826 (2019).

4. Karim, A. M. M. T., Hossain, M. S. \& Khan, M. K. R. Coexistence of cubic and tetragonal phase with colored excitonic emissions in mixed halide Perovskite $\mathrm{CH}_{3} \mathrm{NH}_{3} \mathrm{PbI}_{3-\mathrm{x}} \mathrm{Cl}_{\mathrm{x}}$ thin film. J. Phys. Conf. Ser. 1412, 132016 (2020).

5. Karim, A. M. M. T. et al. Structural, opto-electronic characteristics and second harmonic generation of solution processed $\mathrm{CH}_{3} \mathrm{NH}_{3} \mathrm{PbI}_{3-\mathrm{x}} \mathrm{Cl}_{\mathrm{x}}$ thin film prepared by spray pyrolysis. Mater. Sci. Eng. B 54, 11818-11826 (2020).

6. Wehrenfennig, C., Eperon, G. E., Johnston, M. B., Snaith, H. J. \& Herz, L. M. High charge carrier mobilities and lifetimes in organolead trihalide perovskites. Adv. Mater. 26, 1584-1589 (2014).

7. Jin, H. et al. It's a trap! On the nature of localised states and charge trapping in lead halide perovskites. Mater. Horiz. 7, 397-410 (2020).

8. Polushkin, A. S., Tiguntseva, E. Y., Pushkarev, A. P. \& Makarov, S. V. Single-particle perovskite lasers: From material properties to cavity design. Nano Photon. 9, 599-610 (2020).

9. Srivastava, P. \& Bag, M. Elucidating tuneable ambipolar charge transport and field induced bleaching at $\mathrm{CH}_{3} \mathrm{NH}_{3} \mathrm{PbI}_{3} /$ electrolyte interface. Phys. Chem. Chem. Phys. 22, 11062-11074 (2020).

10. Hoke, E. T. et al. Reversible photo-induced trap formation in mixed-halide hybrid perovskites for photovoltaics. Chem. Sci. 6, 613-617 (2015).

11. Xu, J. et al. Triple-halide wide-band gap perovskites with suppressed phase segregation for efficient tandems. Science 367, 1097-1104 (2020).

12. La-O-Vorakiat, C. et al. Elucidating the role of disorder and free-carrier recombination kinetics in $\mathrm{CH}_{3} \mathrm{NH}_{3} \mathrm{PbI}_{3}$ perovskite films. Nat. Commun. 7, 11054 (2016)

13. Zhai, Y. et al. Individual electron and hole mobilities in lead-halide perovskites revealed by noncontact methods. ACS Energy Lett. 5, 47-55 (2020).

14. Stranks, S. D. et al. Electron-hole diffusion lengths exceeding 1 micrometer in an organometal trihalide perovskite absorber. Science 342, 341 (2013)

15. Paraecattil, A. A., Jonghe-Risse, J. D., Pranculis, V., Teuscher, J. \& Moser, J.-E. Dynamics of photocarrier separation in $\mathrm{MAPbI}_{3}$ perovskite multigrain films under a quasistatic electric field. J. Phys. Chem. C 120, 19595-19602 (2016).

16. Emin, S., Pavlica, E., Okuyucu, H., Valant, M. \& Bratina, G. Charge carrier transport in polycrystalline $\mathrm{CH}_{3} \mathrm{NH}_{3} \mathrm{PbI}_{3}$ perovskite thin films in a lateral direction characterized by time-of-flight photoconductivity. Mater. Chem. Phys. 220, 182-189 (2018).

17. Wang, Q. et al. Qualifying composition dependent $\mathrm{p}$ and $\mathrm{n}$ self-doping in $\mathrm{CH}_{3} \mathrm{NH}_{3} \mathrm{PbI}_{3}$. Appl. Phys. Lett. 105, 163508 (2014).

18. Baikie, T. et al. Synthesis and crystal chemistry of the hybrid perovskite $\left(\mathrm{CH}_{3} \mathrm{NH}_{3}\right) \mathrm{PbI}_{3}$ for solid-state sensitised solar cell applications. J. Mater. Chem. A 1, 5628-5641 (2013).

19. Milot, R. L., Eperon, G. E., Snaith, H. J., Johnston, M. B. \& Herz, L. M. Temperature-dependent charge-carrier dynamics in $\mathrm{CH}_{3} \mathrm{NH}_{3} \mathrm{PbI}_{3}$ perovskite thin films. Adv. Funct. Mater. 25, 6218-6227 (2015).

20. Chen, Y. et al. Extended carrier lifetimes and diffusion in hybrid perovskites revealed by Hall effect and photoconductivity measurements. Nat. Commun. 7, 12253 (2016).

21. Wiktor, J., Ambrosio, F. \& Pasquarello, A. Mechanism suppressing charge recombination at iodine defects in $\mathrm{CH}_{3} \mathrm{NH}_{3} \mathrm{PbI}_{3}$ by polaron formation. J. Mater. Chem. A 6, 16863-16867 (2018).

22. Meggiolaro, D., Ambrosio, F., Mosconi, E., Mahata, A. \& Angelis, F. D. Polarons in metal halide perovskites. Adv. Energy Mater. 10, 1902748 (2019).

23. Zheng, F. \& Wang, L.-W. Large polaron formation and its effect on electron transport in hybrid perovskite. Energy Environ. Sci. 12, 1219-1230 (2019).

24. Baranowski, M. \& Plochocka, P. Excitons in metal-halide perovskites. Adv. Energy Mater. 10, 1903659 (2020).

25. Jin, L., Qian, Y., Zhang, Y., Bowen, M. \& Ding, S. Polaronic transport in $\mathrm{CH}_{3} \mathrm{NH}_{3} \mathrm{PbI}_{3}$ single crystals. J. Mater. Sci. Mater. Electron. 31, 1945-1950 (2020).

26. Yin, W-J., Shi, T. \& Yan, Y. Unusual defect physics in $\mathrm{CH}_{3} \mathrm{NH}_{3} \mathrm{PbI}_{3}$ perovskite solar cell absorber. Appl. Phys. Lett. 104, 063903 (2014).

27. Frolova, L. A., Dremova, N. N. \& Troshin, P. A. The chemical origin of the p-type and n-type doping effects in the hybrid methylammonium-lead iodide $\left(\mathrm{MAPbI}_{3}\right)$ perovskite solar cells. Chem. Commun. 51, 14917 (2015).

28. Wehrenfennig, C., Liu, M., Snaith, H. J., Johnston, M. B. \& Herz, L. M. Charge-carrier dynamics in vapour-deposited films of the organolead halide perovskite $\mathrm{CH}_{3} \mathrm{NH}_{3} \mathrm{PbI}_{3-\mathrm{x}} \mathrm{Cl}_{\mathrm{x}}$. Energy Environ. Sci. 7, 2269-2275 (2014).

29. Karakus, M. et al. Phonon-electron scattering limits free charge mobility in methylammonium lead iodide perovskites. J. Phys. Chem. Lett. 6, 4991-4996 (2015).

30. Hutter, E. M., Eperon, G. E., Stranks, S. D. \& Savenije, T. J. Charge carriers in planar and meso-structured organic-inorganic perovskites: Mobilities, lifetimes, and concentrations of trap states. J. Phys. Chem. Lett. 6, 3082-3090 (2015).

31. Ponseca, C. S. Jr. et al. Organometal halide perovskite solar cell materials rationalized: Ultrafast charge generation, high and microsecond-long balanced mobilities, and slow recombination. J. Am. Chem. Soc. 136, 5189-5192 (2014).

32. Reid, O. G., Yang, M., Kopidakis, N., Zhu, K. \& Rumbles, G. Grain-size limited mobility in methylammonium lead iodide perovskite thin-films. ACS Energy Lett. 1, 561-565 (2016).

33. Stranks, S. D. \& Plochocka, P. The influence of the Rashba effect. Nat. Mater. 17, 377-384 (2018).

34. Dong, Q. et al. Electron-hole diffusion lengths $>175 \mu \mathrm{m}$ in solution-grown $\mathrm{CH}_{3} \mathrm{NH}_{3} \mathrm{PbI}_{3}$ single crystals. Science 347, 967-970 (2015).

35. Miyata, A. et al. Direct measurement of the exciton binding energy and effective masses for charge carriers in organic-inorganic tri-halide perovskites. Nat. Phys. 11, 582-587 (2015).

36. Yu, C.-J. Advances in modelling and simulation of halide perovskites for solar cell applications. J. Phys. Energy 1, 022001 (2019).

37. Davies, C. L. et al. Bimolecular recombination in methylammonium lead triiodide perovskite is an inverse absorption process. Nat. Commun. 9, 293 (2018).

38. Menendez-Proupin, E., Palacios, P., Wahnon, P. \& Conesa, J. C. Self-consistent relativistic band structure of the $\mathrm{CH}_{3} \mathrm{NH}_{3} \mathrm{PbI}_{3}$ perovskite. Phys. Rev. B 90, 045207 (2014).

39. Ashari-Astani, N. et al. Computational characterization of the dependence of halide perovskite effective masses on chemical composition and structure. J. Phys. Chem. C. 121, 23886-23895 (2017).

40. Feynman, R. P. Slow electrons in a polar crystal. Phys. Rev. 97, 660 (1955).

41. Kazmerski, L. L. Polycrystalline and Amorphous Thin Films and Devices (Academic Press, 1980). 
42. Ong, K. P., Goh, T. W., Xu, Q. \& Huan, A. Mechanical origin of the structural phase transition in methylammonium lead iodide $\mathrm{CH}_{3} \mathrm{NH}_{3} \mathrm{PbI}_{3}$. J. Phys. Chem. Lett. 6, 681-685 (2015).

43. Quarti, C. et al. Structural and optical properties of methylammonium lead iodide across the tetragonal to cubic phase transition: Implications for perovskite solar cells. Energy Environ. Sci. 9, 155-163 (2016).

44. Jiang, J., Liu, F., Tranca, I., Shen, Q. \& Tao, S. Atomistic and electronic origin of phase instability of metal halide perovskites. ACS Appl. Energy Mater. 3, 11548-11558 (2020).

45. Eames, C. et al. Ionic transport in hybrid lead iodide perovskite solar cells. Nat. Commun. 6, 7497 (2015).

46. Frost, J. M. \& Walsh, A. What is moving in hybrid halide perovskite solar cells?. Acc. Chem. Res. 49, 528-535 (2016).

47. Futscher, M. H. et al. Quantification of ion migration in $\mathrm{CH}_{3} \mathrm{NH}_{3} \mathrm{PbI}_{3}$ perovskite solar cells by transient capacitance measurements. Mater. Horiz. 6, 1497-1503 (2019).

48. Khassaf, H., Yadavalli, S. K., Zhou, Y., Padture, N. P. \& Kingon, A. I. Effect of grain boundaries on charge transport in methylammonium lead iodide perovskite thin films. J. Phys. Chem. C 123, 5321-5325 (2019).

\section{Author contributions}

A.M.M.T.K. designed the project, conducted all measurements, analyzed the data and wrote the manuscript. M.K.R.K. conceives and designed the project, analyzed the data, wrote the manuscript and supervised the whole work. M.S.H. designed and supervised the project. All authors reviewed the manuscript.

\section{Competing interests}

The authors declare no competing interests.

\section{Additional information}

Supplementary Information The online version contains supplementary material available at https://doi.org/ 10.1038/s41598-021-90247-x.

Correspondence and requests for materials should be addressed to A.M.M.T.K. or M.K.R.K.

Reprints and permissions information is available at www.nature.com/reprints.

Publisher's note Springer Nature remains neutral with regard to jurisdictional claims in published maps and institutional affiliations.

Open Access This article is licensed under a Creative Commons Attribution 4.0 International License, which permits use, sharing, adaptation, distribution and reproduction in any medium or format, as long as you give appropriate credit to the original author(s) and the source, provide a link to the Creative Commons licence, and indicate if changes were made. The images or other third party material in this article are included in the article's Creative Commons licence, unless indicated otherwise in a credit line to the material. If material is not included in the article's Creative Commons licence and your intended use is not permitted by statutory regulation or exceeds the permitted use, you will need to obtain permission directly from the copyright holder. To view a copy of this licence, visit http://creativecommons.org/licenses/by/4.0/.

(C) The Author(s) 2021 